\title{
Strategic Management in Vietnam State-Owned Enterprises (SOE)
}

\author{
Nguyen Thanh Hai ${ }^{1}$ \\ ${ }^{1}$ Vietnam University of Commerce, Hanoi, Vietnam \\ Correspondence: Nguyen Thanh Hai, Vietnam University of Commerce, Mai Dich-Cau Giay district, Hanoi, \\ Vietnam. Tel: 84-43-764-3219. E-mail: haint@dhtm.edu.vn \\ Received: November 23, 2015 \\ Accepted: January 6, 2016 \\ Online Published: January 23, 2016 \\ doi:10.5539/ijbm.v11n2p197 \\ URL: http://dx.doi.org/10.5539/ijbm.v11n2p197
}

\begin{abstract}
This paper analyzes the strategic management in SOEs on the basis of a survey of 73 SOEs in Vietnam. The findings have shown that very few SOEs have a section in charge of strategic planning; they are more likely to make decisions based on the subjective experiences of leaders. Though numerous innovations have been recorded in activities of studying business philosophy, mission, objectives of Vietnam's SOEs, these have still not totally escaped from a habit of falling into the old ways of thinking; there have still been many limitations in activities of forecasting external environment and external forecasting. The personnel system, despite the reforming, restructuring steps being under way, is still very completed at present. Activities of testing, assessing, correcting still largely for form's sake, without clear objectives. From the research findings, the paper proposes several solutions in order to improve the performance of strategic management in Vietnam's SOEs.
\end{abstract}

Keywords: public management, strategic management, state-owned enterprises, SOE, Vietnam

\section{Introduction}

Since 1980s, the private business develops strongly in the global economy. Face to the indispensable tendency of improving public management, SOE reform firstly was carried out in Germany and later on gradually multiplied all over the world. In 1990s, the term of "administration" in SOEs has been largely and regularly referred to. "Administration" in this period was a premise step which laid emphasis on activity of forming operation strategy and optimizing social factors to create economic values of SOEs.

To look back at the Vietnamese economy, after officially stepping out of the period of centrally-planning for socialist-oriented market economic development, it still depended too largely on SOEs. During that period, the Vietnamese Government concentrated considerably on the process of arranging, renovating, restructuring and streamlining the system of SOEs so as to meet the increasing requirements of the economy as well as to be strong enough to face the system of private enterprises which was in the process of growing, particularly the foreign ones which were penetrating in the Vietnamese market (Do Mai Thanh, 2006; Dang Van My, 2010). SOEs have increasing been minimized, from 12,000 enterprises in 1990 down to 6,000 in 2006; and by 2013, that was 3,199 (General Statistics Office of Vietnam, 2014). Meanwhile, enterprises have been developing rapidly in scope, with the appearance of more and more economic corporations, groups. Several enterprises have confirmed their reputations and positions in the market and even triumphed in competition with big foreign companies.

SOEs in Vietnam today contribute over $30 \%$ of GDP, employing the workforce and capital. SOEs are popular in the areas of public service supply, infrastructure, energy, transportation, telecom... (Nguyen Khuong, 2012). These are all the sectors that have substantial effect on a large part of the population and other economic sectors. They constitute main tools for the State to carry out policies for stabilizing macroeconomy and coping with market fluctuations, especially in the products of economic crises. So, what to do so that SOEs will have a good development strategy and make positive contribution to the general economic performance and national competitiveness? To meet such pressing needs, the system of SOEs in Vietnam must be possessed of a powerful strength, prepared to encounter challenges from competition and crisis. Nevertheless, as internal force of SOEs in our country is still low, whilst operating cost high and the performance not as expected. The paper analyzes deeply activity of strategic management inform SOEs to give the answers to these questions.

\section{Theoretical Framework of Strategic Management in SOEs}

Chandler defined strategy as "the determination of the basic long-term goals and objects of an enterprise, and the 
adoption of courses of action and the location of resources for carrying out these goals." (1962). Porter (1980, 1990) provided a more general concept: "Strategy is an art of creating competitive advantages". So, strategic management can be construed as a combination of decisions and actions expressed through the results of planning, executing and assessing strategies, is designed to achieve long-term objectives of organizations.

Strategic planning and management in SOEs are closely associated with activities by the Government, and its organizational units. According to OECD (Organization for Economic Cooperation and Development, 2005) and (EU) (European Commission, 2010), strategy in SOE involves two main contents. The first on is the strategic management activities that normally involve identifying mission, vision, enterprise value, internal environment and external environment, directed towards long-term activities. Following that are activities of assessing, reporting, overseeing activities for strategy implementation. Secondly, the budget plan for strategy implementation is identified by analyzing the interrelationship between the objects and the results achieved, the indexes for analyzing budget performance used. A strategic plan is successfully created when the management and setting up the budget plan for the strategy are reasonable.

The performance in strategic management depends too largely on the positive role of managers in the agency's strategic orientation activities. This, thus, involves the coordination among sections in strategic implementation and management activities. Moreover, strategic planning is not a rigid process which managers must always know how to employ flexible ways of managing to achieve the set strategy. Therefore, according to Vinzant and Vinzant (1996), strategies in SOEs are usually difficult to employ due to the rigidity of the management mechanism. Nevertheless, once strategic management is skillfully applied, this will help increase enterprise value and the interests achieved (Nartisa et al., 2012).

As to an organization, the strategic management process also complies with the principles of the general strategic management model in the Figure 1 (David, 2006), but with some specific features as follows:

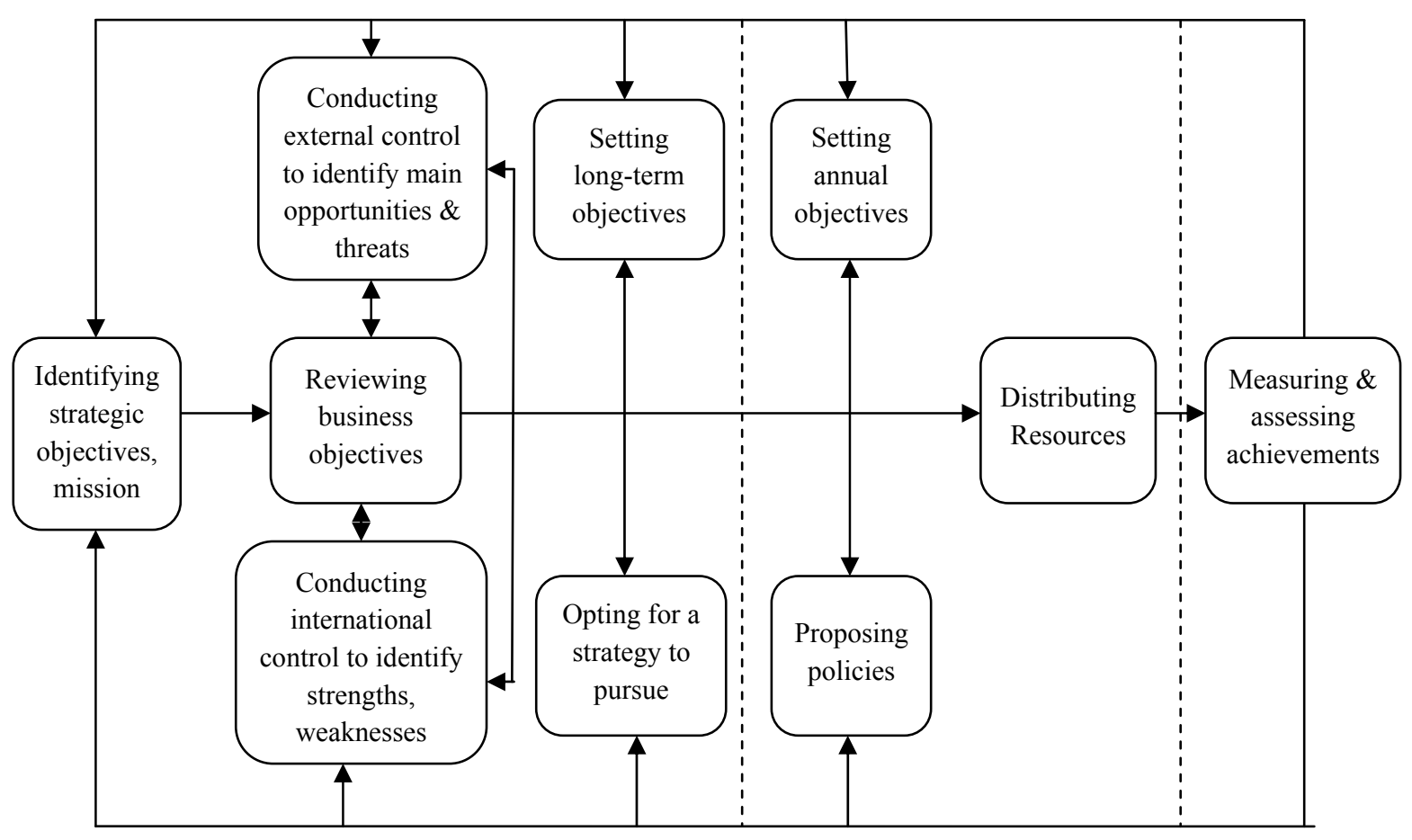

Figure 1. Strategic management model in enterprise

Source: David (2006).

\section{- Defining strategic objectives, mission, vision}

Unlike in private enterprises, leaders of SOEs fall into the categories appointed, assigned by State agencies. Therefore, policy decisions appertaining to SOEs strategic management will partially be related to and influenced by State agencies (Thom \& Ritz, 2008). In many cases, due to heavy dependence on decisions by the State, many enterprises become so chaotic in the process of implementing their enterprise strategies that they 
give up to serving a certain political point of view.

Enterprises strategies are usually created by enterprise leaders. Nevertheless, for SOEs, leaders are appointed by the State and have a period of service as regulated; leaders are also not bound to the enterprise interests but taking general controls (Nartisa et al., 2012). Accordingly, in some cases, a leader only runs the enterprise for a period and then may be seconded or his mission ends; hence the interruption to the enterprise strategy. This is quite contrary to private enterprises.

\section{- Analyzing, forecasting external environment}

Unlike in private enterprises known with market-dynamics, SOEs normally react relatively slowly to market fluctuations as they are under pressure from State agencies (Ring et Perry, 1985). Therefore, foreseeing changes is extremely important. Analyzing the external environmental effects on enterprises is really essential in activities of planning business strategies in the future. SOEs, in the absence of a firm foundation with good forecasters, may consider the option of employing consultant in order to have prompt and accurate results (Joyce, 2000).

\section{- Analyzing corporate internal factors}

Identifying strengths and weaknesses of SOEs is relatively particular due to the fact that numerous policy decisions by enterprises not only bring about separate interests for the enterprises but also effects from the State (Thom \& Ritz, 2008). Moreover, SOEs, with their staff and a complex organizational structure, constitutes a barrier. However, if from that it is possible to gain an insight into nature of enterprises to propose correct policy decisions, then this is an essential issue in strategic management. Operation quality criteria are an approach which can help enterprises measure labour productivity as well as strategic results. This is correct to all enterprise types including enterprise with foreign element (Joyce, 2000).

\section{- Carrying out strategies, testing, assessing, correcting}

Being subject to State management, enterprises have always to disclose in a transparent manner their decisions. The work of leaders thus is also under the always stringent control and inspection by State agencies. Decisions, therefore, are usually made in delay, through numerous discussion steps before arriving at an accurate decision (Nartisa et al., 2012). This expresses the inflexibility like in the private sector. The process of executing strategies of SOEs thus must be very open, without being under compulsion of regulations and processes so as to achieve success.

\section{Methodology}

We study the effects of applying strategic management to direct, manage and create the positioning of SOEs in Vietnam. Further, the data from statistic returns about activities of Vietnamese enterprises in recent years was extracted from the websites of statistics in Vietnam, which constituted a source of secondary data for the writing. This was also a reliable source of data for the research process. Information was reflected in full through the system of statistical data, forms...In addition, the information here was multidimensional, reflecting correctly the actual state of operation of SOEs after strategies for restructuring, merging, etc. of the State. From that, information was reflected in an exact, concise manner, with the right focus, and findings of the strengths and weaknesses of SOEs in Vietnam in strategic management.

In order to obtain authentic information, we conducted a survey of Vietnam's SOEs' strategic management. Questionnaire forms were sent to leaders of SOEs; with the fulfilled questionnaires, after a process of screening and checking for eligibility, 73 enterprises were selected for their eligible answers to be analyzed through SPSS. The survey form is illustrated as in the Figure 2.

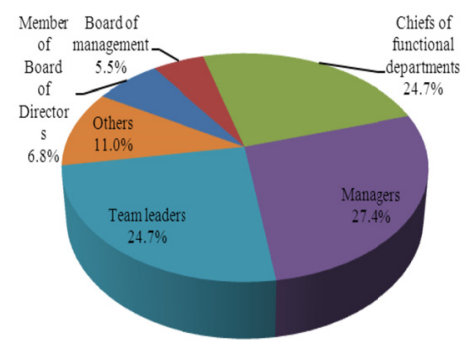

Figure 2. Research sample 


\section{Research Results}

\subsection{Analyzing the Current Strategic Management of Vietnam SOEs}

As never before, the word "Strategy" has been referred to as many as in Vietnam at present. Not only in enterprises with the private or foreign direct investment element, this word also appeared for many times in the course of reforming operations, restructuring SOEs. Nevertheless, to have a proper and sufficient perception of strategy and the importance of strategy is what that not every enterprise can do.

Although the theoretical model has been clear, Vietnam SOEs are still fumbling about in the process of building a development strategy for themselves, particularly in the period of equitization which is taking place very vigorously at the moment.
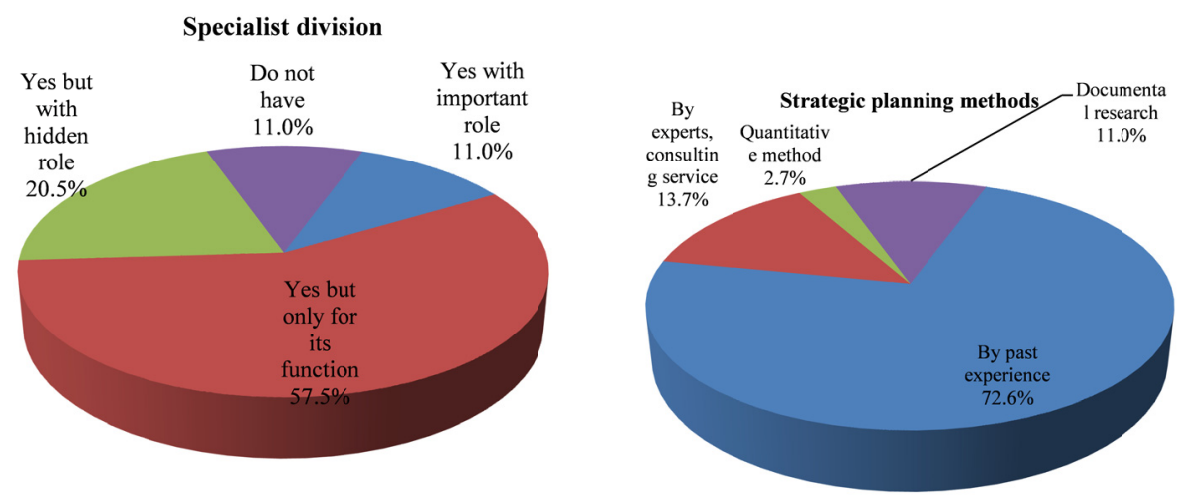

Figure 3. Organization of strategic activates and method of strategic planning in Vietnam SOEs

According to the data collected, of the SOEs having answered the questionnaire compiled by the group, only $11 \%$ had a section in charge of strategic planning, while up to $57.5 \%$ had but not in an intrinsic manner, merely unspecific, without clear orientation).

As to decision-making process in strategic management, most SOEs make decisions based on the subjective past experience of leaders (up to $72.6 \%$ ); $13.7 \%$ of the enterprises based on consulting experts; $11 \%$ based on the theoretical study. Meanwhile, merely $2.7 \%$ of the enterprises based on quantitative analysis of macro and micro environmental factors to make their strategic decisions.

The results of an overall assessment of SOEs' strategic planning activities have shown that the entire strategic planning process of enterprises was at a normal level, without any creative breakthrough. Particularly, the activities of human resource distribution and strategic inspection, assessment and correction are the weaknesses of SOEs in Vietnam when these were rated as completely ineffective or ineffective.

In the strategic management process in Vietnam SOEs, the survey results indicate as follows:

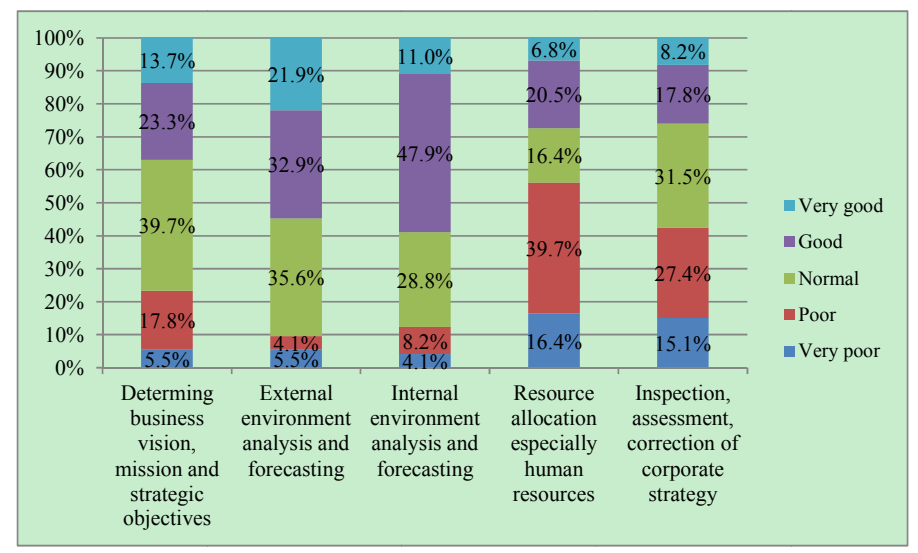

Figure 4. Assessing strategic management in Vietnam SOEs 
Concerning the determination of business vision, mission and strategic objectives: this activities in Vietnam SOEs, despite of several reforms, have still not totally escaped from a habit of falling into the planned economy thinking. Their objectives are usually unspecific, not clear, with such slogans as "strive to fulfill the set objectives". Nevertheless, in many SOEs, these objectives are usually not concretized by figures, by what that can be counted, measured. Vision, mission often appear in big economic groups. Moreover, as to strategic objective planning, most enterprises have their expected short and medium-term objectives (normally under 5 years), without a longer vision of future development planning for 10-20 years to come. This displays the immaturity in terror vision. Enterprises have still actually not realized the importance of strategy in the long term. Failing to have a long-term strategy will seriously affect the entity's financial, personnel... planning.

Concerning the external environment analysis and forecasting: In the current integration process, in order to exist and develop, not only private enterprise but also SOEs have always to find out market tendency, analyze competitors to create a viable sale plan. Reality has shown that in the recent crisis, under the protection of the State, many an enterprise hasn't been able to survive and had to shut down. As a matter of fact, due to poor external environment forecast activities, the subsistence of SOEs is being threatened. The number of SOEs to date has decreased considerably, which was some 949 enterprise 100\% State capital till the end of 2013. Under the roadmap to restructuring of the State, all enterprises shall have to complete equitization by the end of 2015 .

Concerning the internal environment analysis and forecasting: These activities will enable enterprises to find out their own strengths and weaknesses. However, this is a disadvantage of Vietnam's SOEs. A good deal of decisions was made for form's sake, with no clear grounds, mainly based on leader's subjective point of view. As a result, strategies usually cannot wait in front for the market, beyond the capacity of enterprises or cannot make full use of the advantageous that enterprises are possessed of.

Concerning resource allocation especially human resources: Despite the reforming, restructuring steps being under way, the personnel system of State agencies is still very completed at present. This has been the consequence of the previous period, hence the many difficulties in resource allocation of State agencies. Especially, concerning human resources, there exists the phenomenon that numerous officers, employees of State agencies go to their offices but their contributions to the enterprises are relatively small. That many SOEs are effectuating a mechanism of taking early retirement for people who are near retirement age, rearranging jobs for the staff according to their right qualifications constitutes a positive step with which enterprises can fully utilize talented personnel in their right positions thus helping boost enterprise development.

Concerning the inspection, assessment, correction of corporate strategy: As several SOEs are currently in operation but with no clear objectives. Therefore, in order to assess whether an enterprise has fulfilled or not fulfilled its set strategy is relatively difficult. Moreover, as the inspection, control system of enterprises is still considerably poor, not highly flexible, strategic correction activities are rarely referred to.
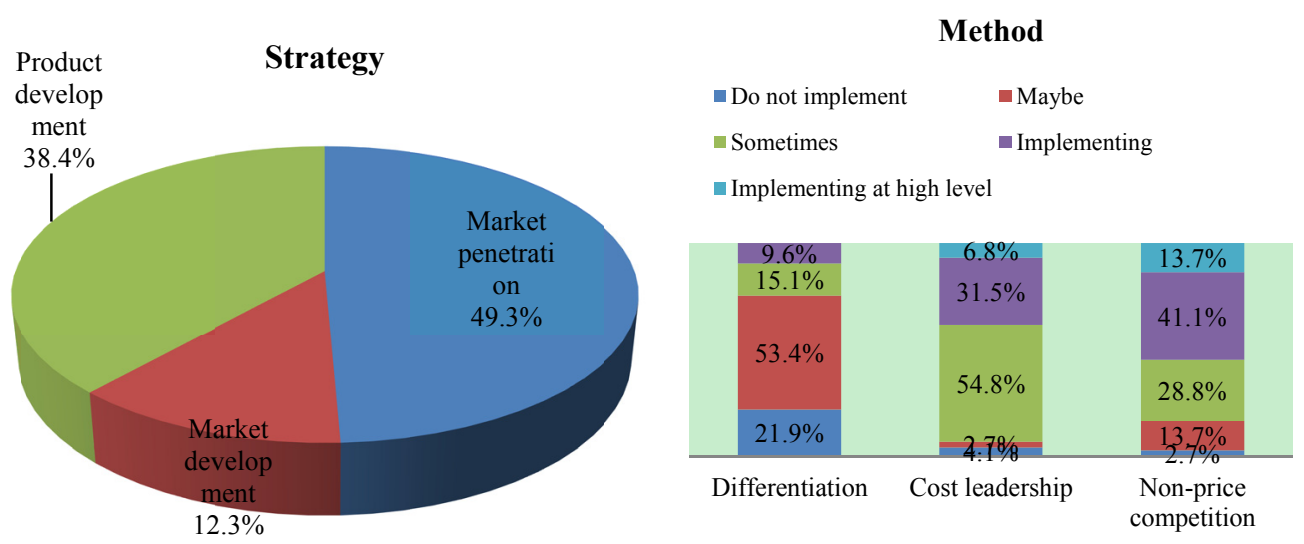

Figure 5. Types of strategies and mode of competition of Vietnam SOEs

Currently, SOEs in Vietnam use three main strategies when wishing to expand their business market: Market penetration strategy (49.3\%), product development strategy (38.4\%) and new market development strategy. The two preferred methods in use when carrying out these strategies are "low cost" and "non-price competition". 
Differentiation strategy is very rarely used and most companies do not opt to this mode for the execution of the strategy they have selected.

\subsection{Assessing Difficulties and Causes}

Presently, special importance has gradually been attached to strategic management in SOEs, however, this is but a beginning step. Assessment of the performance of strategies by SOEs at present has revealed a real state that when writing strategic objectives, enterprises do not draw up specific measures to accompany the objectives. The objectives of enterprises here more often than not are unclear, with no time for implementation and results uncountable and immeasurable. In many cases, it is pointed out by State audit agencies that the objectives set by enterprises are too low or are not closely associated with the nature of the mission entrusted to these enterprises. Business reports lack usually link between the objectives and results. Many Vietnam SOEs say that they are applying some strategy to develop their enterprises. Nevertheless, intrinsically, from employees to leaders, no one can tell clearly what kind of strategy their company is applying is, cannot answer how the procedure for an enterprise to carry out its strategy is. Strategy here is still very vague, unclear.

The biggest difference of SOEs in Vietnam compared with non-State owned enterprises lies in the fact that the rights and interests of enterprise leader are not linked with the prosperity or failure of such enterprises. Leaders are only representatives of the State in administration, management of enterprises. Agencies that lead, manage these State-owned enterprises are chiefly State agencies towards enterprises with $100 \%$ State capital. In many cases, these bodies have the rights to exert direct effects on enterprise policy decisions through administrative orders. There are decisions by State agencies biased towards regulating macro-economy, implementing socio-economic policies while disregarding the practical interests of enterprises. This is the main cause that leads to the fact that SOEs at present can hardly compete with private enterprise in the market.

Furthermore, leader appointment is usually decided by State agencies. Decision criteria more often than not are not dependent on management capacity, business talent of officers but on appointment according to ranks, civil service employee appointment under State regulations. This is far different from the selection criteria for leaders who make policy decisions in enterprise strategic management activities. Their contributions to the enterprises are therefore usually very small. In addition, as these enterprises' operation objectives are usually included in the objectives of macro-economy management of the State, forming a strategic criterion in enterprise management activities is normally very difficult.

\section{Implications of the Results}

In recent time, when Vietnam economy is being integrating deeper and deeper into the world economy, SOEs constitute an important part in the process of economic development. Therefore, in order to cope with competitive pressures from the private sector as well as from foreign enterprises, several recommendations are proposed in order to improve strategic management capacity in SOEs as follows:

For State management agencies, firstly, they should be well aware of the role of strategic management activities in the enterprise operating process. From that, there should be restrictions on decisions in the political nature that directly affect enterprise development. Secondly, in the issue of leader appointment of SOEs, State agencies should look for talented, dutiful people with firm knowledge about corporate management so as to indirectly impact the strategic management activities of that enterprise. Thirdly, State agencies should also be active in propagandizing about the impact of strategic management on enterprises; hold training, refresher training courses for enterprise leaders; restructure organization model, mode of operation of enterprises to conform to international standards.

For SOEs themselves, firstly, they should attach special importance to building initial strategy, with identifying specific objectives, vision, mission on a long term basis, rather than restricted to planning on a medium or short-term basis as before. Operation objectives should be split into specific parts, with a fixed time for fulfilling such objectives. So, only by doing so can enterprise have specific orientation towards making action plans to achieve the objectives.

Secondly, a great attention should be paid to building or restructuring the strategic management system. This system involves building organizational structure, policies, regulations, processes, operations; defining clearly specific duties, functions of each department, section; linking personal responsibility with work quality and executor's interests. Also, as strategy is a long process, enterprises should always be flexible in particular circumstances when determining clearly that their strategy is being misdirected compared with the tempo of development of the economy.

Thirdly, a sufficient database should be built with the lines of business related to the enterprise. In this way, the 
enterprise activities of economic forecasting as well as analyzing competitors will be more reliable and the research findings will probably be used. If the enterprise finds collecting information difficult or its data source insufficient, it should consider employing consultant experts with lots of experience in strategic planning to ensure strategic planning is being in the right direction.

Fourthly, SOEs should always identify its strengths and weaknesses so as to find out the best operation direction. To have a good grasp of its operations to carry out suitable business strategies shall be a prerequisite leading to success of the enterprise.

Fifthly, they should have a system for controlling, assessing work quality in a specific manner. Any operation process needs to be assessed to withdraw experience and to improve and make management suitable. The enterprise may employ methods of assessing like Balanced Scorecard (BSC) or establishing helps the enterprise realize the effectiveness of its strategic management activities.

Sixthly, they should develop qualified human resources. Any enterprise wishing to develop, apart from a good operation orientation, it also needs human resources that can satisfy the requirements. Therefore, SOEs should have a roadmap for recruiting, training its staff in an intrinsic manner. Human resource development must meet the changes in science and technology and conditions of economic integration, especially since Vietnam succeeded in signing the Trans-Pacific Partnership (TPP) trade agreement. Good, professional staff, leader with a general view on strategies will enable the enterprise to cope with challenges and can compete with non-State owned enterprises in the market as well.

\section{Concluding Remarks}

In any stage, any period, strategic management is also indispensable in the existence and development process of enterprises. Correct strategic models will impulse that enterprise to create a panoramic picture of the modes, methods that the enterprise should carry out to make success. Presently, with the rapid development of science and technology, the boom in information with unexpected factors in the world economy, business strategic planning is extremely important. Particularly on October 5, 2015 recently, Vietnam concluded the Trans-Pacific Partnership (TPP) trade agreement, Vietnam's enterprises will have to be confronted with the very drastic competition from foreign enterprises. Vietnam's SOEs, with the State's previous protection, should have operation orientations and build its operation strategy in a specific manner so as to face big changes.

To propose strategy for an enterprise is not an easy job to do; it is a long-term research process of administrators. A good strategy must conform to the actual operation situation of hat SOE; the important thing is that the enterprise's resources must be suitable for the needs of strategic management activities. Therefore, SOEs must always be able to regulate the link between strategic objectives and personnel structure. State and its management agencies thus should have an overview so as to provide proper and strategies. As Vietnam's SOEs are in the process of integrating into the world economy, enterprises should propose correct policies, create suitable strategies so as to subsist and develop in the present period.

\section{References}

Chandler, A. D. (1962). Strategy and Structure: Chapters in the History of the American Industrial Enterprise. Cambridge, MA: MIT Press.

Dang, V. M. (2010). Tập đoàn kinh tế: Định hướng chiến lược kinh doanh trong bối cảnh toàn cầu hóa. Tạp chi Khoa học và Công nghệ, Đại học Đà Nẵng, số 5(40)/2010, Đà Nẵng.

David, A. A. (2006). Strategic Marketing Management.

Do, M. T. (2006). Nhìn lại quá trình cổ phần hóa DNNN ở nước ta. Tạp chí Cộng sản, số 102/2006.

European Commission. (2010). Europe 2020. Strategy for smart, sustainable and inclusive growth. Communication from the commission. Brussels. Retrieved from http://eur-lex.europa.eu/legal-content/EN/TXT/?uri=celex:52010DC2020

General Statistics Office of Vietnam. (2014). Statistical Yearbook of Vietnam 2014. General Statistics Office of Vietnam.

Joyce, P. (2000). Strategy in the public sector (1st ed.). John Wiley \& Sons Ltd, West Sussex.

Nartisa, I., Putans, R., \& Muravska, T. (2012). Strategic planning and management in public and private sector organizations in Europe: Comparative analysis and opportunities for improvement. European Integration Studies, 6. http://dx.doi.org/10.5755/j01.eis.0.6.1538

Nguyen, K. (2012). Tập đoàn kinh tế: Mô hình quản lý và chiến lược phát triển-An economic group: A 
model of management and development strategy. Tạp chi Khoa học ĐHQGHN, Kinh tế và Kinh doanh, $28,16-22$.

OECD. (2005), Paris Declaration and Accra Agenda for Action. OECD. Retrieved from http://www.oecd.org/dac/effectiveness/34428351.pdf

Porter, M. E. (1980). Competitive Strategy: Techniques for Analyzing Industries and Competitors. New York: Free Press.

Porter, M. E. (1990). The Competitive Advantage of Nations. Free Press.

Ring P. S., \& Perry J. L. (1985). Strategic management in public and private organizations: Implications of distinctive contexts and constraints. Academy of Management Review, 10, 276-286.

Thom N., R. A. (2008). Public Management (4th ed.). Betriebswirtschaftlicher Verlag, Wiesbaden.

Vinzant, C. J., \& Vinzant, D. H. (1996). Strategic management and total quality management: Challenges and choices. Public Administration Quarterly, 20, 201-219.

\section{Copyrights}

Copyright for this article is retained by the author(s), with first publication rights granted to the journal.

This is an open-access article distributed under the terms and conditions of the Creative Commons Attribution license (http://creativecommons.org/licenses/by/3.0/). 